\section{Quality Assessment and Yield of Baikal Skullcap (Scutellaria baicalensis) Grown at Multiple Locations}

\author{
Valtcho D. Zheljazkovi,3 \\ Mississippi State University, North Mississippi Research and Extension \\ Center, 5421 Highway 145 South, Verona, MS 38879 \\ Charles L. Cantrell ${ }^{2}$ \\ Natural Products Utilization Research Unit, Agricultural Research Service, \\ U.S. Department of Agriculture, P.O. Box 8048, University, MS 38677
}

M. Wayne Ebelhar ${ }^{1}$

Delta Research and Extension Center, P.O. Box 197, Stoneville, MS 38776

Christine Coker ${ }^{1}$

South Mississippi Branch Experiment Station, Box 193, Poplarville, MS 39470

William B. Evans ${ }^{1}$

Truck Crops Experiment Station, P.O. Box 231, Crystal Springs MS 39059

Additional index words. apigenin, baicalin, baicalein, chrysin, scutellarein, Scutellaria baicalensis

Abstract. Baikal skullcap (Scutellaria baicalensis) is an important medicinal plant with proven bioactivity. Commercially available products in the United States containing extracts or derivatives from this plant species have been shown to lack consistency of chemical composition and bioactivity. In the United States, these issues could be solved through domestic production of skullcap. The hypothesis of this study was that Baikal skullcap grown in the Mississippi climate would accumulate sufficient bioactive flavonoids, baicalin, and baicalein in the roots to justify domestic production, and that shoots of these plants might also contain the flavonoids of interest. A replicated field experiment was conducted at four locations in Mississippi (Beaumont, Crystal Springs, Stoneville, and Verona) to test the hypothesis. The concentration of the main flavonoid, baicalin, in the roots ranged from $8.1 \%$ to $15.6 \%$, whereas the concentration of baicalein varied from $0.2 \%$ to $1.2 \%$. The flavonoid concentrations in the roots were similar to that of commercially available skullcap roots, and to concentrations reported in the literature. Chrysin was detected in the roots from one location. Furthermore, the flavonoids apigenin, baicalein, baicalin, chrysin, and scutellarein were detected and quantified in the skullcap shoots. Overall, yields of dry roots tended to increase from southern to northern locations. This is the first report on flavonoid accumulation in Baikal skullcap roots and shoots grown in the United States. The results from this study are promising and suggest that 1) Baikal skullcap grown in Mississippi accumulates similar amounts of baicalein and baicalin to skullcap grown in other regions and can provide up to $128 \mathrm{~kg} \cdot \mathrm{ha}^{-1}$ of baicalin and up to $2.32 \mathrm{~kg} \cdot \mathrm{ha}^{-1}$ of baicalein; 2) flavonoid concentration in Baikal skullcap roots and shoots, yields, and mineral concentration of roots might depend on climatic and growing conditions; and 3) Baikal skullcap could be developed as a high-value crop for Mississippi and possibly other regions of the United States. Further research is needed on skullcap production methods and economic feasibility.

Received for publication 15 Feb. 2007. Accepted for publication 6 Apr. 2007.

This research was funded by ARS Specific Coop. Agreement 58-6402-4-026 with CRIS MIS172050. Specific project: Field Establishment of Medicinal Herbs and Potential for Commercial Production, awarded to Dr. Jeliazkov (Zheljazkov). Contribution of the Mississippi Agricultural and Forestry Expt. Sta. journal article no. J-11078.

We thank Thomas Horgan, Davis Clark, Michael Ely, and Peter Hudson for their help with the field experiments; and Solomon Green III for assistance with quantitative analysis. We also thank the internal reviewers Dr. David Nagel, Dr. Guihong $\mathrm{Bi}$, and Dr. Crofton Sloan.

${ }^{1}$ Research Assistant Professor.

${ }^{2}$ Research Chemist.

${ }^{3}$ To whom correspondence should be addressed; e-mailvj40@pss.msstate.edu baicalin and baicalein may exhibit anti-HIV activity (Wu et al., 2001), may reduce susceptibility to HIV-1 infection (Li et al., 2000), may have anticancer activity (Ciesielska et al., 2002; Ye et al., 2002), can have protective effects against cytotoxicity and genotoxicity (Hwang et al., 2005), have antioxidant effects (Ciesielska et al., 2002; Shao et al., 2004), and exhibit antidepressant activity (Zhu et al., 2006). Research has also suggested that baicalin and baicalein might also have a potential for chemoprevention of Alzheimer's disease (Heo et al., 2004). Currently, there are several commercially available pharmaceutical drugs that contain baicalein and baicalin from Baikal skullcap (Ciesielska et al., 2002), along with many herbal remedies (Azhunova et al., 2005; Cheng et al., 2002; Di et al., 2006) and botanical extracts (Ye et al., 2004) derived from skullcap roots. However, recent research has demonstrated a great variation in composition and biological activity of commercially available skullcap extracts in the United States, China, and other countries (Ye et al., 2004), with some extracts lacking any bioactivity at all. These results were most probably the result of problems associated with plant identification, genetic variability, ecological conditions, harvest management, and extraction procedures (Ye et al., 2004). The problems with consistency of composition and biological activity of commercially available products from this plant could be resolved through production of Baikal skullcap in the United States with good agricultural practices. Domestic production may also provide a new cash crop for U.S. growers.

Traditional medicine has been using only the roots of Baikal skullcap, because of the greater concentration of baicalin and baicalein in roots compared with the shoots. Currently, only the skullcap roots are harvested and used for baicalin and bacalein production or for plant extracts and other pharmaceuticals. Some researchers, however, found that the shoot extract had greater biological activity than the root extract (Pershina et al., 2000), opening the possibility of using Baikal skullcap shoots.

Most of the commercial products containing baicalin and baicalein, skullcap roots, or extracts currently found on the U.S. market are imported from other countries. The potential for domestic production of Baikal skullcap has been suggested (Craker and Giblette, 2001); however, domestic production of skullcap in the United States has not been investigated. To our knowledge, this is the first study addressing growing Baikal skullcap in the United States. The hypothesis of this study was that Baikal skullcap grown in the Mississippi conditions would accumulate sufficient baicalin and baicalein in the roots to justify domestic production, and that shoots of Baikal skullcap produced in Mississippi may also contain the flavonoids of interest. Furthermore, skullcap may have the potential to be developed as a high-value crop for Mississippi and the southern United States. 


\section{Materials And Methods}

Plant materials and growing conditions. A replicated field experiment was conducted in 2006 at four locations in Mississippi: Beaumont, Crystal Springs, Stoneville, and Verona, representing four major geographical regions of Mississippi (Fig. 1) using Baikal skullcap ( $S$. baicalensis Georgi.). Certified skullcap seeds were obtained from Richter's, Ontario, Canada. Plants for all locations were started in one greenhouse in Verona in March, from seeds in 48-cell plastic trays by placing two to three seeds in every cell and thinning to one plant per cell after emergence. The growth medium was Metromix 300 (a mix of vermiculate, peat, and perlite; The Scotts Co., Marysville, $\mathrm{OH})$. Skullcap plants were grown for $40 \mathrm{~d}$ inside the greenhouse under natural light with a day temperature of 22 to $25^{\circ} \mathrm{C}$ and a night temperature of $18{ }^{\circ} \mathrm{C}$ Plants were irrigated once every $24 \mathrm{~h}$ throughout seedling production. Each tray was fertilized weekly with 1.8 g $20 \mathrm{~N}-20 \mathrm{P}_{2} \mathrm{O}_{5}-20 \mathrm{~K}_{2} \mathrm{O}$ dissolved in $300 \mathrm{~mL}$ water.

Skullcap seedlings were transplanted into the field at the four locations in May 2006 in prepared raised beds covered with a black tices in this part of the country. Soils were analyzed for extractable nutrients at the Mississippi State University Soil Testing Laboratory. Land preparation included disking plastic to reflect common horticultural pracsampled before land preparation and were

and preparation of raised beds using a press pan-type bed shaper, which also covered the beds with black plastic mulch and placed a drip-tape irrigation tube in the middle of the bed under the plastic. Beds were $15 \mathrm{~cm}$ high and $75 \mathrm{~cm}$ wide across the top and were spaced $1.8 \mathrm{~m}$ apart (from the center of one bed to the center of the next bed). Two rows of skullcap transplants were spaced $30 \mathrm{~cm}$ apart, in an offset pattern, with an in-row spacing of $30 \mathrm{~cm}$, on the top of each bed. Plots were $1 \times 6 \mathrm{~m}$, with 40 plants in each plot. Four plots (replicates) were maintained per location. The experimental design was a randomized complete-block design. Plants were irrigated weekly as needed through the subsurface drip tape centered on the bed and 4 to $5 \mathrm{~cm}$ below the soil surface. Fertilizer (N, $\mathrm{P}$, and $\mathrm{K}$ ) was supplied with irrigation water via the drip tape to provide 120,80 , and 100 $\mathrm{kg} \cdot \mathrm{ha} \mathrm{a}^{-1}$ of $\mathrm{N}, \mathrm{P}_{2} \mathrm{O}_{5}$, and $\mathrm{K}_{2} \mathrm{O}$, respectively, over the growing season. Weed control in all locations was efficient with the black plastic. However, yellow nutsedge (Cyperus esculentus) and purple nutsedge (C. rotundus) were able to grow through the plastic and had to be removed by hand. No pest control was necessary during the growing season at any of the locations. Plants were harvested in July, at full bloom at each location, by cutting the shoots 3 to $4 \mathrm{~cm}$ above the soil and carefully excavating the roots. The roots and the shoots were cleaned of soil particles, air-dried at temperatures up to $40{ }^{\circ} \mathrm{C}$, and stored until further analysis.

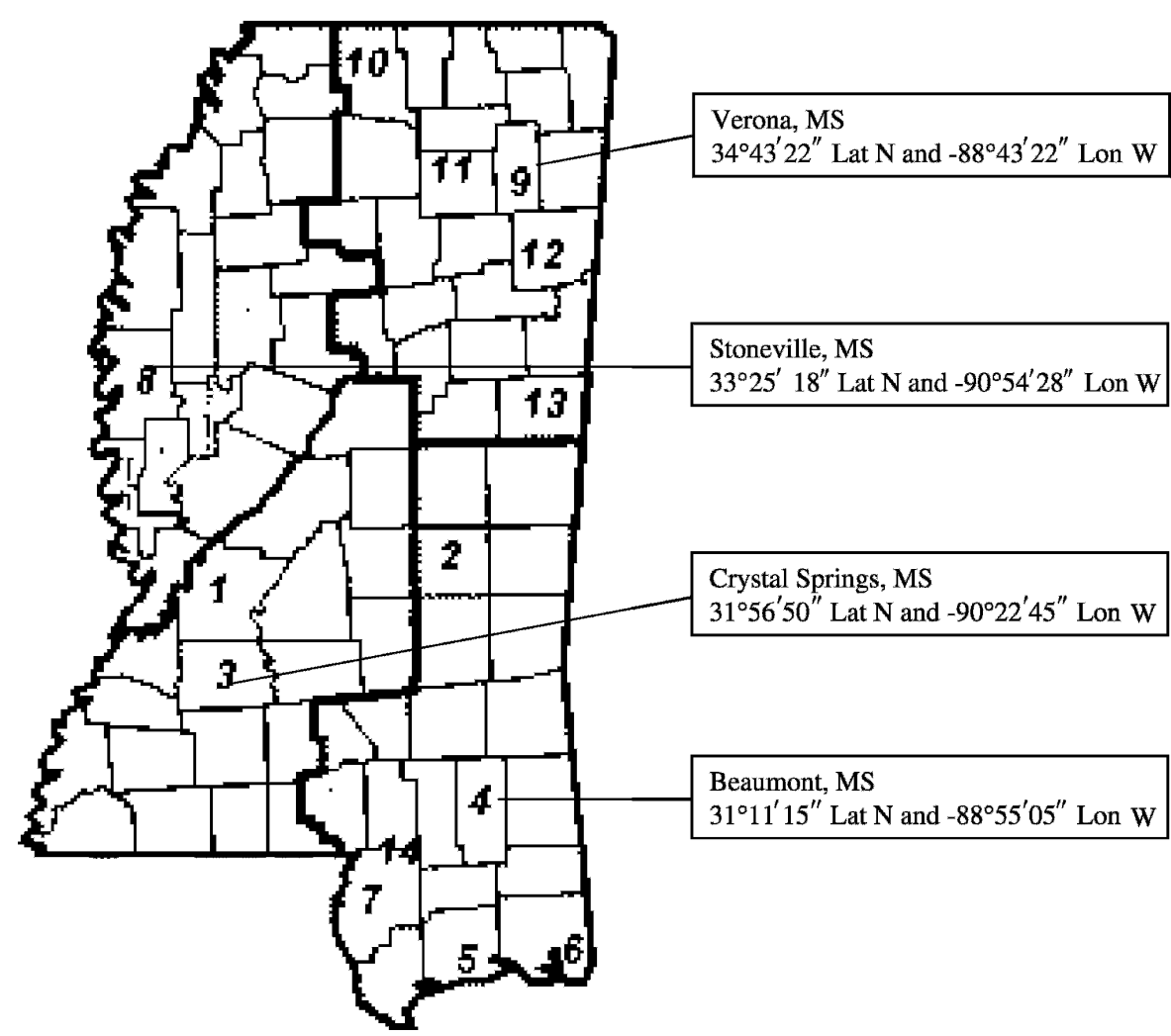

Fig. 1. Map of Mississippi with indication of the counties and the Mississippi Agriculture and Forestry Expt. Sta. (MAFES; 1-14). The field experiments were conducted at the MAFES research stations in Beaumont (4), Crystal Springs (3), Stoneville (8), and Verona (9).
All four sites had a different soil type (Table 1). The soil at Beaumont was McLaurin sandy loam (coarse-loamy, siliceous, subactive, thermic, Typic Paleudults), the soil in Crystal Springs was Providence silt loam (fine-silty, mixed, active, thermic, Oxyaquic Fragiudalfs), the soil in Stoneville was Bosket very fine sandy loam (fine-loamy, mixed, active, thermic Millic Hapludalfs), the soil in Verona was Quitman sandy loam (fine-loamy, siliceous, semiactive, thermic, Aquic Paleudult), and had dissimilar concentrations of extractable nutrients (Table 1).

Chemicals and standards for flavonoid analysis. Flavonoid content was established using the dried roots and shoots from the four locations. In addition to samples obtained from the four locations, a commercial sample of Baikal skullcap dry roots was purchased from Pacific Botanical, LLC (Grants Pass, OR) and analyzed in triplicate. Shoots from Baikal skullcap were not commercially available. High-performance liquid chromatographygrade solvents methanol $(\mathrm{MeOH}$; ultraviolet c.o.205) and acetonitrile (ultraviolet c.o.190) were purchased from Fisher Scientific (Waltham, MA), and formic acid (95\%) was purchased from Sigma (St. Louis, MO). Flavone standards baicalein (98\%) and baicalin $(95 \%)$ were purchased from Aldrich (St. Louis, MO). Apigenin (98\%), chrysin (pure), scutellarein (pure), and 6-hydroxyflavone $(97 \%)$ were purchased from Infodine Chemical Company Inc. (Hillsborough, NJ). For analysis, baicalein and baicalin were dissolved in ethanol, and the balance was dissolved in 70 methanol: 29 deionized water: 1 formic acid by volume.

Sample preparation and extraction of flavonoids. Roots and shoots were homogenized using a Waring laboratory blender (Waring Laboratory \& Science, Torrington, CT) and stored at $2.4{ }^{\circ} \mathrm{C}$ until extraction. Representative subsamples of roots $(0.2 \mathrm{~g})$ and shoots $(0.5 \mathrm{~g})$ were taken from every sample. The roots and shoots subsamples were placed in volumetric flasks and extracted with $100 \mathrm{~mL} 70 \mathrm{MeOH}: 29 \mathrm{H}_{2} \mathrm{O}$ : $1 \mathrm{CH}_{2} \mathrm{O}_{2}$ (by volume) in a Branson 2510 ultrasonic bath (Branson, Danbury, CT) at $65^{\circ} \mathrm{C}$ for 120 min using a previously described method (Horvath et al., 2005). Each extracted standard and sample was then filtered with a Millex-FG (Millipore, Billerica, MA) PTFE Fluoropore $0.20-\mu \mathrm{m}$ filter. With the exception of apigenin, $5 \mathrm{mg}$ of each flavanoid standard was dissolved in $25 \mathrm{~mL} 70 \mathrm{MeOH}$ : $29 \mathrm{H}_{2} \mathrm{O}: 1 \mathrm{CH}_{2} \mathrm{O}_{2}$ (by volume) and analyzed at $0.2 \mathrm{mg} \cdot \mathrm{mL}^{-1}$. Apigenin was dissolved into $\mathrm{MeOH}$ with sonication.

High-performance liquid chromatography analysis. Samples and standards were analyzed on an Agilent 1100 series high-performance liquid chromatograph (Agilent, Palo Alto, $\mathrm{CA}$ ) equipped with a vacuum degasser, quaternary pump, autosampler, and diode array detector (DAD). An Agilent Zorbax SB-C18 $4.6 \times 250-\mathrm{mm}, 5-\mu \mathrm{m}$ column was used for this analysis with an injection volume of $10 \mu \mathrm{L}$ for all standards and samples. All sample and standard injections were analyzed 
Table 1. Selected initial soil characteristics $(0-15 \mathrm{~cm})$, the concentration of extractable nutrients in the soil, and the average daily minimum and maximum temperatures of the four locations in Mississippi.

\begin{tabular}{|c|c|c|c|c|c|c|c|c|c|c|c|c|}
\hline Location & Soil type & $\mathrm{pH}$ & OM & $\begin{array}{c}\mathrm{P} \\
\left(\mathrm{kg} \cdot \mathrm{ha}^{-1}\right)\end{array}$ & $\begin{array}{c}\mathrm{K} \\
\left(\mathrm{kg} \cdot \mathrm{ha}^{-1}\right)\end{array}$ & $\begin{array}{c}\mathrm{Ca} \\
\left(\mathrm{kg} \cdot \mathrm{ha}^{-1}\right)\end{array}$ & $\begin{array}{c}\mathrm{Mg} \\
\left(\mathrm{kg} \cdot \mathrm{ha}^{-1}\right)\end{array}$ & $\begin{array}{c}\mathrm{Zn} \\
\left(\mathrm{kg} \cdot \mathrm{ha}^{-1}\right)\end{array}$ & $\begin{array}{c}\mathrm{S} \\
\left(\mathrm{kg} \cdot \mathrm{ha}^{-1}\right)\end{array}$ & $\begin{array}{c}\mathrm{Na} \\
\left(\mathrm{kg} \cdot \mathrm{ha}^{-1}\right)\end{array}$ & $\begin{array}{c}\operatorname{Max} \mathrm{T}^{\mathrm{y}} \\
\left({ }^{\circ} \mathrm{C}\right)\end{array}$ & $\begin{array}{c}\operatorname{Min} \mathrm{T} \\
\left({ }^{\circ} \mathrm{C}\right)\end{array}$ \\
\hline Beaumont & $\begin{array}{l}\text { McLaurin sandy } \\
\text { loam }\end{array}$ & 5.8 & $0.67 \mathrm{~b}$ & $240 a^{z}$ & $268 \mathrm{~b}$ & $731 \mathrm{~b}$ & $99 \mathrm{c}$ & 2.01 & 109 & $136 \mathrm{~b}$ & 33.4 & 18.3 \\
\hline Crystal Springs & $\begin{array}{l}\text { Providence silt } \\
\text { loam }\end{array}$ & 5.7 & $0.96 \mathrm{a}$ & $172 a b$ & $363 \mathrm{a}$ & $2172 \mathrm{a}$ & $174 \mathrm{~b}$ & 2.01 & 155 & $120 \mathrm{~b}$ & 31.7 & 18.1 \\
\hline Stoneville & $\begin{array}{l}\text { Bosket very } \\
\text { fine sandy loam }\end{array}$ & 6.7 & $0.95 \mathrm{a}$ & $103 \mathrm{~b}$ & $401 \mathrm{a}$ & 2933 a & $526 \mathrm{a}$ & 4.8 & 153 & $360 \mathrm{a}$ & 31.1 & 18.3 \\
\hline Verona & $\begin{array}{l}\text { Quitman sandy } \\
\text { loam }\end{array}$ & 6.5 & $1.02 \mathrm{a}$ & $64 \mathrm{c}$ & $132 \mathrm{c}$ & $2140 \mathrm{a}$ & $123 \mathrm{bc}$ & 1.15 & 160 & $132 \mathrm{~b}$ & 30.1 & 17.2 \\
\hline
\end{tabular}

${ }^{\mathrm{z}}$ Means within columns followed by different letters are significantly different at $P<0.05$.

y The average daily maximum and minimum temperatures were averaged from the daily maximum and minimum temperatures at the four locations for the period 1 May through 31 Oct.

OM, organic matter; T, temperature.

at room temperature using a linear gradient from $80 \%: 20 \%\left(\mathrm{H}_{2} \mathrm{O}\right.$ with $0.1 \%$ TFA: $\left.\mathrm{MeOH}\right)$ to $20 \%: 80 \%\left(\mathrm{H}_{2} \mathrm{O}\right.$ with $0.1 \%$ TFA:MeOH$)$ over $30 \mathrm{~min}$ followed by holding at $20 \%: 80 \%$ for $5 \mathrm{~min}$ and reequilibration. Analytes were detected at $280 \mathrm{~nm}$ with a reference of $450 \mathrm{~nm}$ by the DAD. Representative chromatograms of roots and leaves are shown in Figs. 2 and 3 respectively.

Quantitative analysis of the flavonoids. With five concentration points, an external standard least squares regression for quantification was used. All six analytes were used to formulate separate calibration curves using a detector response at $280 \mathrm{~nm}$. Linearity was assessed using response factors (RFs) and regression coefficients independently. The chromatogram of each extracted sample was compared with those of the standard injections, and the target peaks were confirmed by both retention time and ultraviolet spectra at $280 \mathrm{~nm}$. Confirmed integrated peaks were then used to determine the flavonoid dry weight percentage. The RFs of the target flavonoid were used to determine the percent in biomass for each location or commercial sample. A flavonoid average (average percent in biomass) consisting of each location representative was used to chart the dry weight percentage.

Nutrient analyses of soil and plant tissue. Air-dried soil samples were extracted using the Lancaster soil test method (Cox, 2001), and the tissue samples were "dry-ashed" using standard procedures of the Mississippi State University Chemistry Laboratory. The concentration of nutrients in soil and plant tissue extracts was measured with an inductively coupled argon plasma spectrometer (Thermo Jarrell Ash, Franklin, MA).

Data analyses of yield data sets were performed using one-way analysis of variance in Quattro Pro 10.

\section{Results}

The soil properties at the four locations were distinctly different. Overall, Beaumont soil was lower in organic matter, with relatively low $\mathrm{pH}$, and had lower concentrations of extractable $\mathrm{Ca}, \mathrm{Mg}$, and $\mathrm{S}$, but contained higher extractable $\mathrm{P}$, relative to the soil from other locations (Table 1).

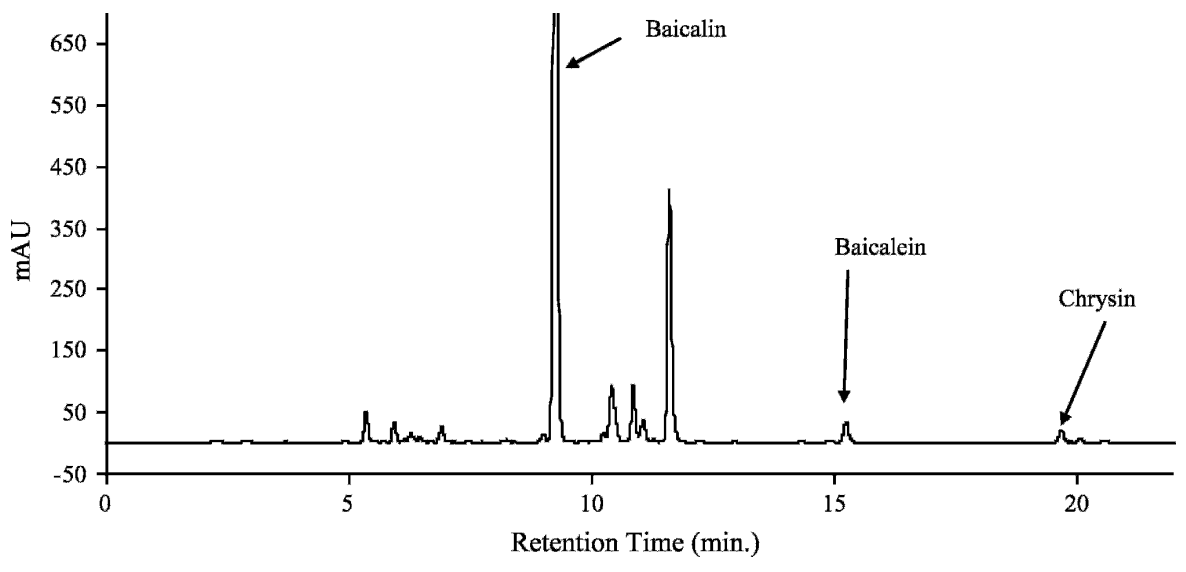

Fig. 2. Representative chromatogram at $280 \mathrm{~nm}$ of Scutellaria baicalensis roots grown in Beaumont.

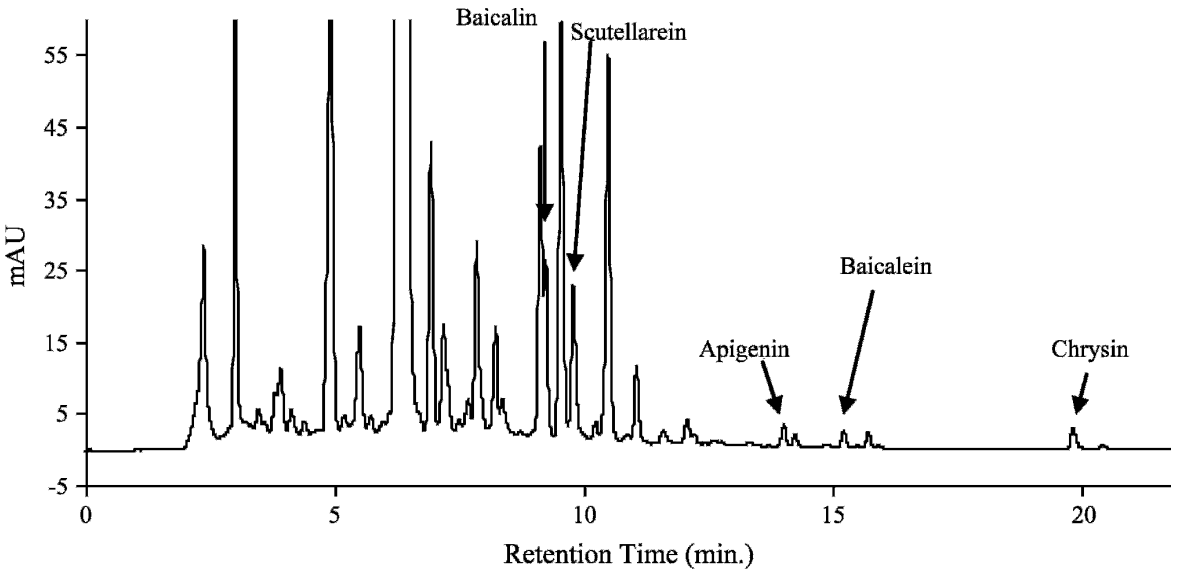

Fig. 3. Representative chromatogram at $280 \mathrm{~nm}$ of Scutellaria baicalensis shoots (herbage) grown in Verona.

The concentration of the main flavonoid baicalin in the roots of skullcap grown in Mississippi ranged from $8.1 \%$ to $15.6 \%$, similar to the baicalin concentration in the commercial sample, which was $14.5 \%$ (Table $2)$. Baicalin concentration in skullcap roots produced in Mississippi varied depending on location. The highest baicalin concentration in roots was measured in plants produced in Crystal Springs; the lowest baicalin concentration was found in roots produced in Beaumont. However, roots produced at Beaumont contained the highest concentration of baica- lein, the other major flavonoid in skullcap roots. Chrysin was detected only in roots produced in Beaumont, indicating an effect of location.

Overall, the flavonoid concentration in skullcap shoots (herbage) in this study was relatively low (Table 3 ) compared with the flavonoid concentration in the roots. Also, the chemical profile of skullcap roots was distinctly different from the chemical profile of the shoots (Figs. 2 and 3 ). We were able to detect and quantify apigenin, baicalein, baicalin, chrysin, and scutellarein in skullcap 
shoots produced at Verona and at Beaumont (with the exception of baicalin), and only scutellarein was detected and quantified in the shoots from Crystal Springs.

Yields of skullcap roots in Verona were about six times higher than in Beaumont and two times higher than in Stoneville or in Crystal Springs (Table 2), indicating a tendency of increasing yields from south (Beaumont) to north (Verona; Fig. 1). Skullcap root yields were positively correlated to soil organic matter and increase in soil $\mathrm{pH}$, and were negatively correlated to soil extractable $\mathrm{P}$ and $\mathrm{K}$ (Tables 1 and 2). The calculated yield of baicalin varied from 15 to 128 $\mathrm{kg} \cdot \mathrm{ha}^{-1}$, whereas the calculated yield of baicalein varied from 0.97 to $2.32 \mathrm{~kg} \cdot \mathrm{ha}^{-1}$. Nutrient concentration of skullcap roots (Table 4) did not correlate well with extractable concentration of nutrients in the soil (Table 1). The concentration of $\mathrm{N}, \mathrm{K}, \mathrm{Fe}, \mathrm{Mn}$, and $\mathrm{Cu}$ in skullcap roots varied depending on location (Table 4). Overall, less variation in nutrient concentration of roots was observed for $\mathrm{P}, \mathrm{Ca}, \mathrm{Mg}, \mathrm{S}, \mathrm{Zn}$, and $\mathrm{B}$. Nitrogen concentration in the commercial sample of skullcap was higher, whereas the concentration of $\mathrm{Fe}$ and $\mathrm{Mn}$ was very low compared with roots grown in Mississippi (Table 4).

\section{Discussion}

We found that the concentration of the main flavonoid baicalin in the roots of skullcap grown in four locations in Mississippi was similar to the concentration reported from other producing locations (Bochorakova et al., 2003; Horvath et al., 2005), which confirmed our hypothesis. Also, to our knowledge, this is the first report on the effect of location on the accumulation of baicalein and baicalin in skullcap. The dissimilar flavonoid profile of skullcap grown in Beaumont could be the result of several factors: 1) higher temperatures throughout the growing season (Table 1) or 2) soil properties such as physical characteristics, $\mathrm{pH}$, and the plant available concentration of nutrients.

Our data suggest that growing conditions could alter flavonoid content in skullcap. However, there are many factors that might have influenced flavonoid profile of skullcap at Beaumont (e.g., soil type, $\mathrm{pH}$, extractable nutrients, temperature; Table 1), suggesting the need for further research on the effect of temperature, soil properties, and nutrient levels on the chemical profile of skullcap.

The flavonoid concentration in skullcap shoots (herbage) in this study was relatively low, confirming the general understanding that only the roots of this species contain high amounts of flavonoids (Bochorakova et al., 2003; Horvath et al., 2005). As indicated earlier, no commercial sample of Baikal skullcap shoots was available because, traditionally (and unlike other Scutellaria species), only the roots from this species are used for baicalein and baicalin production (Joshee et al., 2002). In our study, the shoot concentration of apigenin was higher, baicalin was lower, and chrysin was similar compared with the concentration of skullcap roots grown outside the United States and reported recently by Zgorka (2006).

Data collected from this study suggest that location (including soil characteristics such as soil organic matter, $\mathrm{pH}$, and extract-

Table 2. Yields and flavonoid concentration in skullcap roots at four locations in Mississippi.

\begin{tabular}{lcccccc}
\hline & Root dry yield & \multicolumn{2}{c}{ Baicalin } & \multicolumn{2}{c}{ Baicalein } & Chrysin \\
\cline { 3 - 6 } \cline { 5 - 7 } Location & $\left(\mathrm{kg} \cdot \mathrm{ha}^{-1}\right)$ & $\% \pm \mathrm{SD}$ & $\mathrm{kg} \cdot \mathrm{ha}^{-1}$ & $\% \pm \mathrm{SD}$ & $\mathrm{kg} \cdot \mathrm{ha}^{-1}$ & $(\% \pm \mathrm{sD})$ \\
\hline Beaumont & $184 \mathrm{c}^{\mathrm{z}}$ & $8.1 \pm 1.6$ & 15 & $1.2 \pm 0.17$ & 2.202 & $0.261 \pm 0.027$ \\
Crystal Springs & $476 \mathrm{~b}$ & $15.6 \pm 1.9$ & 74 & $0.334 \pm 0.09$ & 1.589 & n.d. \\
Stoneville & $464 \mathrm{~b}$ & $13.6 \pm 3$ & 63 & $0.21 \pm 0.03$ & 0.97 & n.d. \\
Verona & $1173 \mathrm{a}$ & $10.9 \pm 1.7$ & 128 & $0.198 \pm 0.03$ & 2.322 & n.d. \\
Commercial sample & - & $14.5 \pm 0.625$ & - & $0.310 \pm 0.038$ & - & n.d. \\
\hline
\end{tabular}

${ }^{\mathrm{z}}$ Means within columns followed by different letters are significantly different at $P<0.05$. n.d., not detected or below the detection limit. Apigenin, scutellarein, and 6-hydroxyflavone were either not detected or below the limit of detection.

Table 3. Concentration of flavonoids (measured as percent \pm SD) in dry shoot biomass of Scutellaria baicalensis grown at four locations in Mississippi.

\begin{tabular}{lccccc}
\hline Location & Apigenin & Baicalein & Baicalin & Chrysin & Scutellarein \\
\hline Beaumont & $0.03 \pm 0.01$ & $0.007 \pm 0.013$ & n.d. & $0.004 \pm 0.0023$ & $0.333 \pm 0.17$ \\
Crystal Springs & n.d. & n.d. & n.d. & n.d. & $0.112 \pm 0.06$ \\
Stoneville & n.d. & n.d. & n.d. & n.d. & n.d. \\
Verona & $0.012 \pm 0.003$ & $0.003 \pm 0.006$ & $0.1 \pm 0.003$ & $0.006 \pm 0.002$ & $0.074 \pm 0.03$ \\
\hline
\end{tabular}

n.d., not detected, or below the detection limit. 6-Hydroxyflavone was either not detected or below the limit of detection. able nutrients) may have an effect on skullcap dry root yields, and the root yields increased from southern to northern location. Our data also indicate that mineral nutrient concentration of skullcap roots may depend on location; however, plant nutrient concentration could not be predicted by the concentration of available nutrients in soil. A longer term study and evaluation of other production methods are needed to estimate the production potential of Baikal skullcap in the southern United States.

Although the need for domestic production of skullcap has been suggested (Craker and Giblette, 2001; Joshee et al., 2002), this is the first study of the possibilities for domestic production of Baikal skullcap in the United States. This is also the first study of Baikal skullcap in Mississippi and the southern United States, and the first study demonstrating that Baikal skullcap roots produced in the southern United States can have a similar concentration of baicalein and baicalin as the commercially available skullcap roots (Table 2 ) and as reported in the literature (Bochorakova et al., 2003). Our results also suggest the possibility for production of not only Baikal skullcap roots but also shoots.

\section{Conclusion}

From this preliminary work at multiple locations, it has been shown that Baikal skullcap grown in Mississippi accumulates similar concentrations of bacalein and baicalin to skullcap grown in other nations. Baikal skullcap grown in Mississippi can provide up to $128 \mathrm{~kg} \cdot \mathrm{ha}^{-1}$ of baicalin and up to 2.32 $\mathrm{kg} \cdot \mathrm{ha}^{-1}$ of baicalein. The flavonoid concentration in Baikal skullcap roots and shoots might depend on environmental conditions such as temperature and the availability of soil nutrients, whereas the mineral concentration of roots could not be predicted very well by the extractable nutrients in soil. It appears that Baikal skullcap could be developed as a new high-value crop for Mississippi and possibly other regions of the United States. Further research is needed, however, to clarify the effect of environmental conditions and soil physical and chemical properties on the accumulation of flavonoids in skullcap roots and shoots, and on economic feasibility.

\section{Literature Cited}

Azhunova, T.A., Z.G. Sambueva, V.G. Banzaraksheev, and D.B. Dashiev. 2005. Bile-expelling effect of complex natural remedy. Rastitel'nye Resursy 41:112-117.

Bochorakova, H., H. Paulova, J. Slanina, P. Musil, and E. Taborska. 2003. Main flavonoids in the root of Scutellaria baicalensis cultivated in

Table 4. Concentration of nutrients in Scutellaria baicalensis roots grown at the four locations in Mississippi and in a commercial sample.

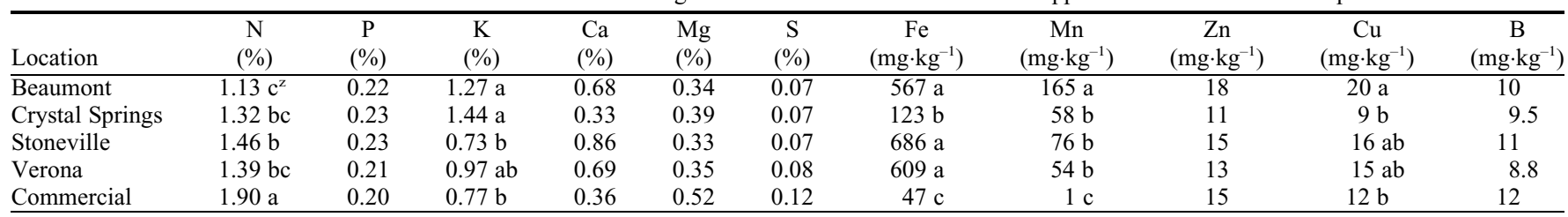

${ }^{\mathrm{z}}$ Means within columns followed by different letters are significantly different at $P<0.05$. 
Europe and their comparative antiradical properties. Phytother. Res. 17:640-644.

Cheng, A.H., M.H. Han, and B.R. Han. 2002. Determination of baicalin content in Longdanxiegan pills using RP-HPLC. Chinese J. Info. Tradit. Chinese Med. 9:46-47.

Ciesielska, E., A. Gwardys, and D. Metodiewa. 2002. Anticancer, antiradical and antioxidative actions of novel Antoksyd S and its major components baicalin and baicalein. Anticancer Res. 22:2885-2892.

Cox, M.S. 2001. The Lancaster soil test method as an alternative to the Mehlich 3 soil test method. Soil Sci. 166:484-489.

Craker, L.E. and J. Giblette. 2001. Chinese medicinal herbs: Opportunities for domestic production, p. 491-496. In: J. Janick and A. Whipkey (eds.). Trends in new crops and new uses Proceedings of the Fifth National Symposium, Atlanta, Georgia, USA, 10-13 Nov. 2001. ASHS Press, Alexandria, VA.

Di, B., N.P. Feng, and W.Y. Liu. 2006. Pharmacokinetic comparisons of Suang-Huang-Lian with the different combinations of its constitutional herbs. J. Ethnopharmacol. 107:401-405.

Heo, H.J., D.O. Kim, S.J. Choi, D.H. Shin, and C.Y. Lee. 2004. Potent inhibitory effect of flavonoids in Scutellaria baicalensis on amyloid beta protein-induced neurotoxicity. J. Agr. Food Chem. 52:4128-4132.

Horvath, C.R., P.A. Martos, and P.K. Saxena. 2005. Identification and quantification of eight flavones in root and shoot tissues of the medicinal plant Huang-qin (Scutellaria baicalensis Georgi) using high-performance liquid chromatography with diode array and mass spectrometric detection. J. Chromatogr. A 1062:199-207.

Hwang, J.M., T.H. Tseng, Y.Y. Tsai, H.J. Lee, F.P. Chou, C.J. Wang, and C.Y. Chu. 2005. Protective effects of baicalein on tert-butyl hydroperoxide-induced hepatic toxicity in rat hepatocytes. J. Biomed. Sci. 12:389-397.

Joshee, N., T.S. Patrick, R.S. Mentreddy, and A.K. Yadav. 2002. Skullcap: Potential medicinal crop, p. 580-586. In: J. Janick and A. Whipkey (eds.). Trends in new crops and new uses. ASHS Press, Alexandria, VA.

Kimura, Y. 2005. Bio-pharmacological action of natural products isolated from medicinal plants-flavonoids (baicalein and baicalin) and stilbenes (resveratrol and cassigarol A). J. Tradit. Med. 22:154-161.

Li, B.Q., T. Fu, Y.O. Dongyan, J.A. Mikovits, F.W Ruscetti, and J.M. Wang. 2000. Flavonoid baicalin inhibits HIV-1 infection at the level of viral entry. Biochem. Biophys. Res. Commun. 276:534-538.

Pershina, O.V., N.I. Suslov, V.I. Litvinenko, and T.P. Popova. 2000. An influence of extract from above-ground part of Scutellaria baicalensis Georgi on elaboration and reproduction of conditioned drinking reflex in normal animals and in animals under alcohol intoxication. Rastitel'nye Resursy 36: 120-124.

Shao, Z.H., T.L. Vnden-oek, C.Q. Li, P.T. Schumacker, L.B. Becker, K.C. Chan, Y.M. Qin, J.J. Yin, and C.S. Yuan. 2004. Synergistic effect of Scutellaria baicalensis and grape seed proanthocyanidins on scavenging reactive oxygen species in vitro. Am. J. Chinese Med. 32:89-95.

U.S. Department of Agriculture, National Resources Conservation Service. 2007. Plants database. Jan. 2007. <http://plants.usda.gov/java/nameSearch $>$.

Wu, J.A.N., A.S. Attele, L. Zhang, and C.S. Yuan. 2001. Anti-HIV activity of medicinal herbs: Usage and potential development. Am. J. Chinese Med. 29:69-81.

Ye, F., H. Wang, S. Jiang, J. Wu, J. Shao, X. Cheng, Y. Tu, and D. Zhang. 2004. Quality evaluation of commercial extracts of Scutellaria baicalensis. Nutr. Cancer 49:217-222.

Ye, F., L. Xui, J. Yi, W.D. Zhang, and D.Y. Zhang. 2002. Anticancer activity of Scutellaria baicalensis and its potential mechanism. J. Altern. Complem. Med. 8:567-572.

Zgorka, G. 2006. Retention behavior of silicabonded and novel polymeric reversed-phase sorbents in studies of flavones and chemotaxonomic markers of Scutellaria L. genus. J. Chromatogr. 1120:230-236.

Zhu, W.L., S.P. Ma, R. Qu, D. Kang, and Y.D. Liu. 2006. Antidepressant effect of baicalin extracted from the root of Scutellaria baicalensis in mice and rats. Pharmacol. Biol. 44:503-510. 